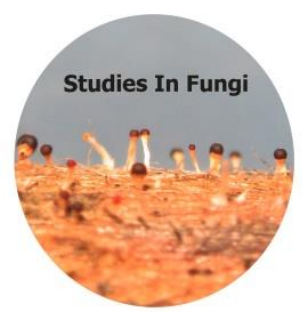

Studies in Fungi 2(1): 112-118 (2017) www.studiesinfungi.org ISSN 2465-4973

Article

Doi 10.5943/sif/ 2/1/13

Copyright $\odot$ Mushroom Research Foundation

\title{
Mycenastrum catimbauense (Agaricales, Basidiomycota), a new puffball species from the Brazilian semi-arid region
}

\author{
Gurgel RAF ${ }^{1}$, Melanda GCS ${ }^{2}$, Ferreira RJ $^{3}$, Alfredo DS $^{2}$ and Baseia IG ${ }^{1,2,3^{*}}$ \\ ${ }^{l}$ Departamento de Botânica e Zoologia, Centro de Biociências, Universidade Federal do Rio Grande do Norte, Av. \\ Senador Salgado Filho, 3000, Campus Universitário, Natal, 59072-970, RN, Brazil \\ ${ }_{2}^{2}$ Programa de Pós-Graduação em Sistemática e Evolução, Centro de Biociências, Universidade Federal do Rio \\ Grande do Norte, Av. Senador Salgado Filho, 3000, Campus Universitário, Natal, 59072-970, RN, Brazil \\ ${ }^{3}$ Programa de Pós-Graduação de Biologia de Fungos, Centro de Ciências Biológicas, Universidade Federal de \\ Pernambuco, Av. Prof. Moraes Rego, 1235, Cidade Universitária, Recife, PE, 50670-901, Brazil
}

Gurgel RAF, Melanda GCS, Ferreira RJ, Alfredo DS, Baseia IG 2017 - Mycenastrum catimbauense (Agaricales, Basidiomycota), a new puffball species from the Brazilian semi-arid region. Studies in Fungi 2(1), 112-118, Doi 10.5943/sif/2/1/13

\begin{abstract}
Mycenastrum catimbauense is found growing in the xerophytic biome named "Caatinga" in the Catimbau National Park, Pernambuco State, Brazil. Basidiomata are found solitary in an open place and exposed to sunlight. The morphological analyses of macro- and microstructures followed the specific literature of the group. The fundamental diagnostic characteristics for this new taxon are the dark-colored peridium and gleba, tomentose peridium and spiny capillitium with brittle thorns. Full description, color photographs of the basidiomata and microstructures of this new species, and a discussion are provided.
\end{abstract}

Key words - Biodiversity - Gasteromycetes - Lycoperdales - Neotropics - Taxonomy

\section{Introduction}

Mycenastrum is an unusual puffball genus, easily recognized by its branched capillitium and covered in numerous thorn-like spines. Desvaux (1842) established this interesting genus based on Lycoperdon corium Guers., which was combined as Mycenastrum corium (Guers.) Desv., becoming the type species of the genus. Over time, some other species (17), subspecies (2) and varietal ranks (5) (Index Fungorum 2017) were proposed. However, some authors consider Mycenastrum corium as a single cosmopolitan species (Hollo's 1904, Cunningham 1944, Bottomley 1948, Pila't 1958, Smith \& Smith 1973, Miller \& Miller 1988, Pegler et al. 1995, Grgurinovic 1997, Hansen \& Knudsen 1997).

The Catimbau National Park is an important conservation area in the Caatinga, an exclusively Brazilian biome. This unique National Park is the second largest archaeological site in Brazil, with a surface area of 62,300 hectares and altitude range of 900-1000 m. It is located in the semi-arid region of Pernambuco State in the transition between distinct vegetation zones, forming a mosaic of landscapes with high biodiversity, including endemic species (Andrade et al. 2004, Gomes et al. 2006).

There is a need for a revision study of the genus Mycenastrum using integrative taxonomy in order to evaluate the real distribution of $M$. corium and to establish the informative characteristics 
for species delimitation within the genus. This work aims to broaden the knowledge of this genus through the description of a new species.

\section{Materials \& Methods}

\section{Collection site details}

Two specimens were collected in the rainy season of 2006 in Catimbau National Park (Fig. 1a). This park is situated in Buique, Pernambuco state, Brazil and its geographical coordinates are $8^{\circ} 37^{\prime} 0.01^{\prime \prime} \mathrm{S}-37^{\circ} 08^{\prime} 60.00 " \mathrm{l}$ (Fig. 1b).

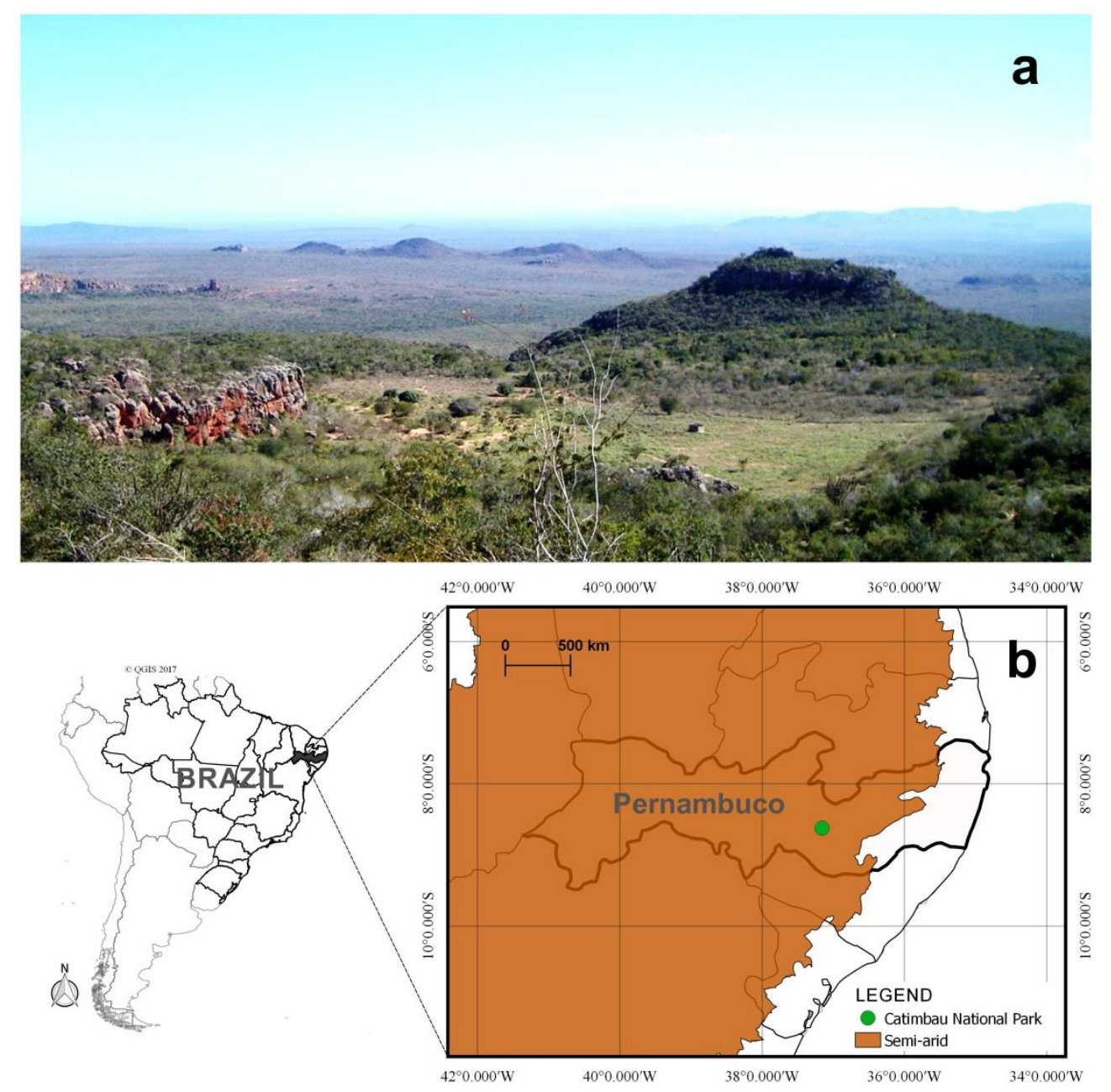

Fig. 1 - Collection site in semi-arid region, Brazil. a. Landscape images from Catimbau National Park. b. Map of Pernambuco State and type locality.

\section{Collection methods}

The specimens were collected following a methodology proposed by Baseia et al. (2014), in which the basidiomata were photographed with scales, georeferenced and removed from the substrate with a pocketknife. In the Biology of Fungi laboratory at the Federal University of Rio Grande do Norte the basidiomata were dehydrated in an electric dehydrator and packaged in a ziplock bag; these were then placed together with an information sheet from the collection.

\section{Morphological observations}

The morphological analysis was conducted according to Demoulin (1968) and Calonge \& Demoulin (1975). Macroscopic characters are based on observations of the dehydrated basidiomas, 
including characteristics of the peridium and gleba. The size, shape and color of these characters were analyzed. Microscopic observation was performed using an optical Nikon Eclipse Ni (LM) microscope with Nikon DS-Ril camera attached and all the measurements were carried out using the NIS-Elements AR v.4.51.00 software. Slides for microscopic analysis were mounted in cotton blue, Melzer's reagent and $\mathrm{KOH} \mathrm{5 \%} \mathrm{containing} \mathrm{portions} \mathrm{of} \mathrm{the} \mathrm{gleba} \mathrm{and} \mathrm{peridium.} \mathrm{For} \mathrm{each}$ specimen, 30 basidiospores were randomly selected and measured, including ornamentation, 20 hyphae of the peridium and gleba and 40 process spines. The statistical measurements used in basidiospores were performed according to Sousa et al. (2014), where measurements were conducted of 30 spores (including ornamentation), which determined the variation of the length $\left(\mathrm{H}_{\text {Min }}\right.$ and $\mathrm{H}_{\mathrm{Max}}$ ) and width ( $\mathrm{W}_{\mathrm{Min}}$ and $\mathrm{W}_{\mathrm{Max}}$ ), the mean of the two dimensions $\left(x_{\mathrm{H}}\right.$ and $\left.x_{\mathrm{W}}\right)$, the standard deviation of these (+/- SD) and the height (h) by the width (w) quotient represented by Qm $\left(\mathrm{H}_{\text {Min }}-\mathrm{H}_{\mathrm{Max}} \times \mathrm{W}_{\text {Min }}-\mathrm{W}_{\mathrm{Max}}\left[x=x_{\mathrm{H}} \pm \mathrm{SD}_{\mathrm{H}} \times x_{\mathrm{W}} \pm \mathrm{SD}_{\mathrm{W}}\right]\right)$ always observed on 100× objective. Scanning electronic microscope (SEM) photography was performed according to Cortez et al. (2008). The color was coded following Kornerup \& Wanscher (1967). The herbarium specimens were deposited in the Fungus Collection of the Federal University of Rio Grande do Norte (UFRN), Natal, Brazil.

\section{Results}

\section{Taxonomy}

Mycenastrum catimbauense Baseia, Gurgel, Melanda, Ferreira R.J. \& Alfredo, sp. nov. Figs 2-4 MycoBank: MB821075; Facesoffungi number: FoF03658. Brazil.

Etymology - In reference to the type locality, Catimbau National Park, Pernambuco State,

Holotype - Brazil, Pernambuco, Buíque, Catimbau National Park (-8 37'0.01" S $37^{\circ} 08^{\prime} 60.00^{\prime \prime} \mathrm{W}$ ) on soil, 3 Aug 2006, T. Ottoni (UFRN Fungos - 2847, holotype! UFRN Fungos 2848).

Diagnosis - Basidiomata $40 \mathrm{~mm}$ wide; peridium tomentose, 1.4-2.1 mm thick, grayish brown to dark brown; dehiscence by fragmentation of endoperidium; gleba dark brown; spiny capillitium, brittle thorns; basidiospores globose, 11.7-14.5 $\mu \mathrm{m}$ diam., pedicelate.

Description - Basidiomata at maturity epigeous, $40 \mathrm{~mm}$ wide, globose to subglobose (Fig. 2); Subgleba absent; Peridium double 1.4-2.1 mm thick divided into exo- and endo-peridium; Exoperidium persistent, papery, 0.14-0.21 mm thick, tomentose, 0.04-0.08 mm length, dark brown (6F4), pruinose surface and amorphous substance forming flakes; Endoperidium persistent, coriaceous, $1.15-1.77 \mathrm{~mm}$ thick, darkish $(6 \mathrm{~F} 2)$ to dark brown $(6 \mathrm{~F} 4)$, delimited by outer layer $1.1-$ $1.7 \mathrm{~mm}$ thick and inner layer 0.02-0.06 mm thick; Dehiscence by rupture of the apical portion of the peridium in irregular pointed rays; Gleba dark brown (6F4), powder releasing easily from peridium. Rhizomorphs not visualized.

Exoperidium composed of interwoven hyphae, 2.6-3.7 [3.13 \pm 0.34$] \mu \mathrm{m}$ diam., wall 0.6-1.3 $[0.91 \pm 0.20] \mu \mathrm{m}$ thick and tortuous, aseptate, clamp connections absent, reduced lumen, dextrinoid, cyanophilous, yellowish in $5 \% \mathrm{KOH}$; Endoperidium composed of outer and inner layer: outer layer, with hyphae (2.4)3.3-5.7 [4.35 \pm 0.60$] \mu \mathrm{m}$ diam., wall 0.3-0.7 [0.54 \pm 0.08$] \mu \mathrm{m}$ thick, aseptate, clamp connections absent, dextrinoid, yellowish in $5 \% \mathrm{KOH}$; inner layer with hyphae 3.24.9(6.0) [4.12 \pm 0.62$] \mu \mathrm{m}$ diam., wall 0.6-1.3 [0.93 \pm 0.15$] \mu \mathrm{m}$ thick, aseptate, clamp connection absent, dextrinoid, cyanophilous, yellowish in 5\% KOH; Capillitium 7-15.7 [10.5 \pm 1.3$] \mu \mathrm{m}$ diam., aseptate, branched, wall 1.1-2.2 [1.64 \pm 0.24$] \mu \mathrm{m}$ thick, spiny capillitium, spines abundant at level of the terminal conical portion, weakly dextrinoid, light brown in $5 \% \mathrm{KOH}$, acyanophilous; Spines of capillitium 3.0-15.9 [7 \pm 2.8$] \mu \mathrm{m} \times 1.3-7.3[2.8 \pm 1.4] \mu \mathrm{m}$, brittle, branched; Basidiospores globose to subglobose, 13.3-15.0 $\times 11.7-14.5[14.0 \pm 0.7 \times 13.2 \pm 0.7, \mathrm{Qm}=1.1] \mu \mathrm{m}$, dextrinoid, acyanophilous, reddish brown in $5 \% \mathrm{KOH}$, reticulate and pedicelate.

Habitat - in open soil of 'Caatinga' biome (dry forest). 
Habit - solitary, not gregarious

Remarks - Mycenastrum catimbauense is a typical species of the genus Mycenastrum. It has a double and thick peridium with the dehiscence occurring from the upper hemisphere, subgleba absent, gleba powdery, spiny capillitium and ornamented basidiospores (Desvaux 1842, Seynes 1869, Long 1930, Bottomley 1948). This species is characterized mainly by its dark tomentose exoperidium, dark brown endoperidium, dark brown gleba (Fig. 3a-d), capillitium with brittle spines (Figs 4a, 4c) and bigger basidiospores measuring 13.3-15.0 $\mu \mathrm{m}$ in diameter (Figs 4b, 4d). These characteristics are closely related to $M$. corium and $M$. corium var. diabolicum.

Mycenastrum corium differs from $M$. catimbauense by having a smooth exoperidium that falls off at maturity, gleba umber to purple-brown and basidiospores smaller $(8.7-13.6 \mu \mathrm{m}$ diam.) (Desvaux 1842, Bottomley 1948, Demoulin 1968, Homrich \& Wright 1973). Moreover, the exoand endo-peridium in $M$. catimbauense have no clamp connection, while in $M$. corium the exoperidium is composed of hyphae with clamp connections and is bigger than in $M$. catimbauense (2.5-7.5 $\mu \mathrm{m}$ diam. vs. 2.6-3.7 $\mu \mathrm{m}$ diam.) (Demoulin 1968, Homrich \& Wright 1973). According to the authors of the species, in $M$. corium the endoperidium is composed of a well-defined double layer with the closest thicknesses of $0.2-0.5 \mathrm{~mm}$. In our analyses, the endoperidium of $M$. catimbauense is composed of an outer layer that is thicker than the inner layer (1.1-1.7 vs. 0.02$0.06 \mathrm{~mm}$ ) (Fig. 3c).

Mycenastrum corium var. diabolicum differs from $M$. catimbauense by having a dark reddish brown peridium, extremely purplish black gleba and smaller pedicelate basidiospores $(9-10 \mu \mathrm{m}$ diam.) (Homrich \& Wrigth 1973). Moreover, in our morphological analyses, the spines of the capillitium are brittle and longer (Fig. 4c) than in M. corium var. diabolicum (15.9 vs. $10.8 \mu \mathrm{m}$ length).
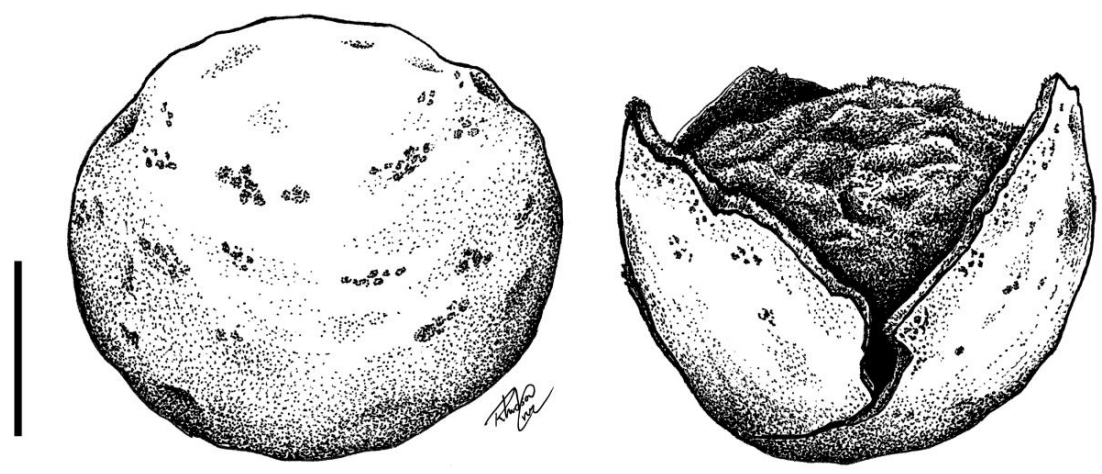

Fig. 2 - Mycenastrum catimbauense. Illustration of the immature fruiting body and with the gleba exposed. Scale bars: $20 \mathrm{~mm}$.

The other Mycenastrum species are not morphologically closed, since they have small spores with other ornamentation, such as echinulate ( $M$. radicatum Durieu \& Montagne), smooth ( $M$. beccarii Passerini, $M$. dugesii De Seynes, M. leiospermum Montagne, M. leptodermeum Durieu \& Montagne M. martinicense Patouillard, M. ohiense Ellis \& Morgan and M. oregonense Ellis \& Everh.), minutely verrucose (M. spinulosum Peck) or verrucose (M. phaeotrichum Berk.) (Berkeley 1843, Fries \& Montagne 1847, Passerini 1875, Peck 1881, Seynes 1886, Cooke \& Massee 1887 and Patouillard 1902). M. olivaceum Cooke \& Massee has spores with approximately the same diameter as M. catimbauense; however, it has asperulate ornamentation (Cooke \& Massee 1887).

Another contribution to defining the new species is the Caatinga biome. This is the only large natural region of Brazil whose limits are entirely restricted to the national territory, and it deserves great attention (Silva et al. 2004). The semi-arid climate, which is typical of the biome, is strongly seasonal, with less than $1000 \mathrm{~mm}$ of rain per year. It presents high potential evapotranspiration, from 1500 to $2000 \mathrm{~mm}$ per year (Velloso et al. 2002). There is rich biodiversity and the biome is very distinct from other habitats. It is a region that has high potential to develop new species. 

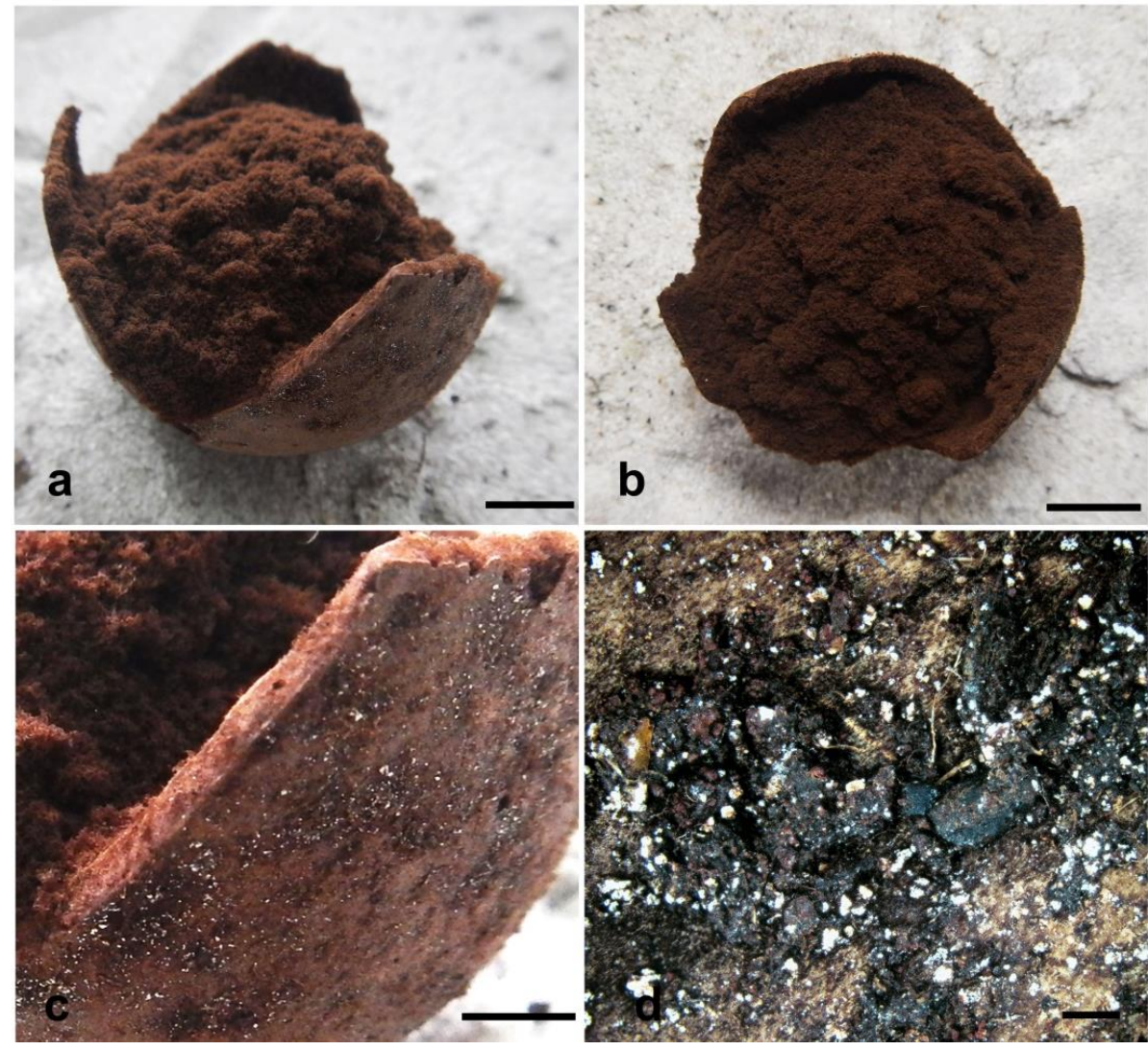

Fig. 3 - Basidiomata in situ. a-b. Mature basidiomata with the gleba exposed. c-d. Detailed tomentose exoperidium. Scale bars: $a-b=10 \mathrm{~mm}, c=5 \mathrm{~mm}, \mathrm{~d}=0.5 \mathrm{~mm}$

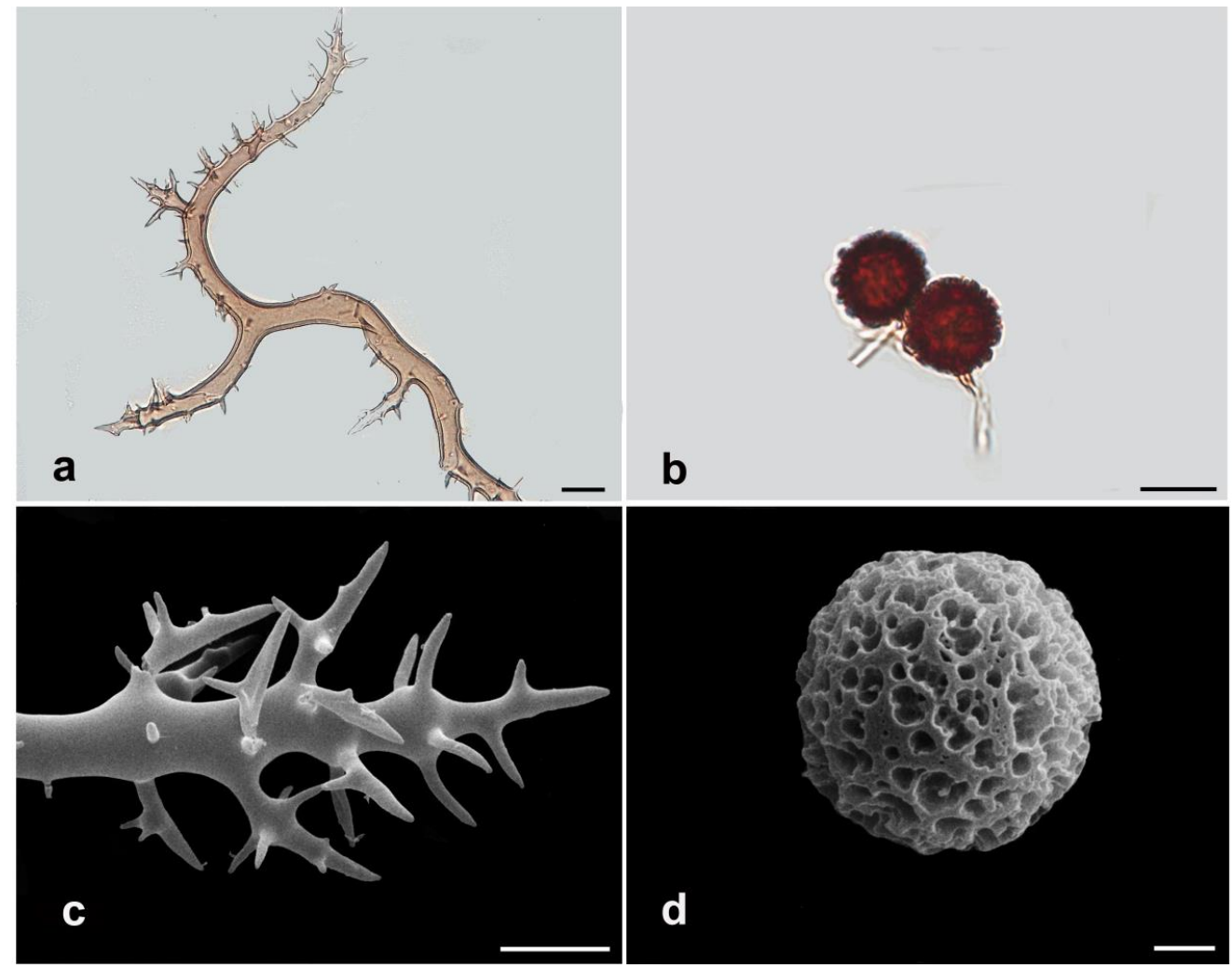

Fig. 4 - Microstructures. a. Capillitium with brittle spines under LM. b. Basidiospores pedicelate under LM. c. Capillitium with brittle thorns under SEM. d. Basidiospores reticulate under SEM. Scale bars: $\mathrm{a}=20 \mu \mathrm{m}, \mathrm{b}-\mathrm{c}=10 \mu \mathrm{m}, \mathrm{d}=2 \mu \mathrm{m}$. 
In recent years, the belief that some gasteroid genera were monotypic, such as Astraeus Morg., Myriostoma Desv. and Pisolithus Alb. \& Schwein., has been revealed by molecular analyses to be wrong. This is mainly due to the universally adopted DNA barcode region for fungi (Schoch et al. 2012), which has unmasked hidden taxa. Distinct species have now been described within these genera and several more await formal naming and description (Phosri et al. 2012, 2013, 2014, Martín et al. 2013, Sousa et al. 2017). In the near future, review studies using integrative taxonomy will probably demonstrate similar results for the genus Mycenastrum.

The Index Fungorum (2017) gives 14 species of Mycenastrum. However, many authors have considered the genus as monospecific and widely distributed (Cunningham 1944, Bottomley 1948, Grgurinovic 1997, Kirk et al. 2008), although new varieties have been proposed (Homrich \& Wright 1973, Miller et al. 2005). Thus, more studies are needed, allying morphological and molecular analyses to clarify the position of the species and variety in Mycenastrum. Unfortunately, despite many attempts, it has so far proved impossible to extract DNA from our specimens, and at times the amplification was contaminated with Aspergillus sp. Thus, in this work we have used a set of macro and micro morphological characteristics to propose Mycenastrum catimbauense as a distinct and reliable species.

\section{Acknowledgments}

The authors would like to express their thanks to the Coordenação de Aperfeiçoamento de Pessoal de Nivel Superior (CAPES-Brazil) for the scholarships awarded to Donis S. Alfredo and Gislaine C. S. Melanda and to the Conselho Nacional de Desenvolvimento Científico e Tecnológico (CNPq-Brazil) for the scholarships awarded to Renato J. Ferreira and Rafaela A. F. Gurgel. Many thanks to the Programa de Capacitação em Taxonomia (PROTAX/ 440612/2015-2) and Projeto de Pesquisa em Biodiversidade do Semiarido (PPBio/457476/2012-5) for scholarships and funding the fieldwork, respectively.

\section{References}

Andrade KVSA, Rodal MJN, Lucena MFA, Gomes APS. 2004 - Composição florística de um trecho do Parque Nacional do Catimbau, Buíque, Pernambuco, Brasil. Hoehnea 31, 337-348.

Baseia IG, Silva BDB, Cruz RHSF. 2014 - Fungos Gasteroides no Semiárido do Nordeste Brasileiro. Rio Grande do Norte-Brasil: Print Mídia pp. 132.

Bottomley AM. 1948 - Gasteromycetes of South Africa. Bothalia Pt. III, pp. 810.

Berkeley MJ. 1843 - Enumeration of fungi, collected by Herr Zeyher in Uitenhage. London Journal of Botany 2, 507-27.

Calonge FD, Demoulin V. 1975 - Gasteromycetes d'Espagne. Bulletin trimestriel de la societe mycologique de France 91(2), 247-292.

Cooke MC, Massee G. 1887 - Australasian fungi. Grevillea 16(77), 30-33.

Cortez VG, Baseia IG, Guerrero RT, Silveira RMB. 2008 - Two sequestrate cortinarioid fungi from Rio Grande do Sul, Brazil. Hoehnea 35, 513-518.

Cunningham GH. 1944 - The Gasteromycetes of Australia and New Zealand. Printed Privately: John McIndoe, pp. 236.

Demoulin VD. 1968 - Gastéromycètes de Belgique: Sclerodermatales, Tulostomatales, Lycoperdales. Bulletindu Jardin botanique national de Belgique 38(1), 1-101.

Desvaux NA. 1842 - Sur le genre Mycenastrum. Annales des Sciences Naturelles Botanique 17, 143-147.

Fries IP, Montagne C. 1847 - Flora D'Algérie. Exploration scientifique de l'Algérie 1,1-598.

Gomes APS, Rodal MJN, Melo AL. 2006 - Florística e fitossociologia da vegetação arbustiva subcaducifólia no Município de Buíque, Pernambuco. Acta Botanica Brasilica 20, 37-48.

Grgurinovic CA. 1997 - Larger Fungi of South Australia. Botanic Garden of Adelaide, pp. 725.

Hansen L, Knudsen H. 1997 - Nordic Macromycetes v.3. Nordsvamp, Copenhagen, pp. 444.

Hollo's L. 1904 - Die Gasteromyceten Ungarns. Oswald Weigel, Leipzig, pp. 210. 
Homrich MH, Wright JE. 1973 - South American Gasteromycetes. The genera Gastropila, Lanopila and Mycenastrum. Mycologia 65, 779-794.

Index Fungorum 2017 - http://www.indexfungorum.org/Names/Names.asp (accessed 30 February 2017).

Kirk P, Cannon PF, Minter DW, Stalpers JA. 2008 - Ainsworth \& Bisby's Dictionary of the Fungi. 10th ed. CAB International, Wallingford, UK, pp. 771.

Kornerup A, Wanscher JH. 1967 - Methuen Handbook of Colour. Ltd. London, England: Methuen and Co., pp. 243.

Long WH. 1930 - The dehiscence of Mycenastrum corium. Mycologia 22(3), 103-105.

Martín MP, Durán F, Phorsi C, Watling R. 2013 - A new species of Pisolithus from Spain. Mycotaxon 124, 149-154.

Miller OKJr, Miller HH. 1988 - Gasteromycetes. Morphology and Development Features with Keys to the Orders, Families, and Genera. Mad River Press, pp. 157.

Miller OKJr, Brace RL, Evenson V. 2005 - A new subspecies of Mycenastrum corium from Colorado. Mycologia 97(2), 530-533.

Passerini G. 1875 - Funghi raccollti in Abissinia dal Signor 0. Beccari. Nuovo Giornale Botanico Italiano 7, 180-192.

Patouillard NT. 1902 - Champignons de la Guadeloupe, recuellis par le R. P. Duss. Bulletin de la Société Mycologique de France (in French) 18(2), 171 - 86.

Peck CH. 1881 - New species of fungi. Botanical Gazette Crawfordsville 6(7), 239-41.

Pegler DN, Laessøe T, Spooner BM. 1995 - British Puffballs Earthstars and Stinkhorns. Royal Botanic Garden, Kew, pp. 255.

Phosri C, Martín MP, Suwannasai N, Sihanonth P, Watling R. 2012 - Pisolithus: a new species from southeast Asia and a new combination. Mycotaxon 120, 195-208.

Phosri C, Martín MP, Watling R. 2013 - Astraeus: hidden dimensions. IMA Fungus 4(2), 347-356.

Phosri C, Watling R, Suwannasai N, Wilson A, Martín MP. 2014 - A new representative of starshaped Fungi: Astraeus sirindhorniae sp. nov. from Thailand. PloS ONE 9(5), e71160.

Pila' t A. 1958 - Flora, SR Gasteromycetes. Praha, pp. 862.

Schoch CL, Seifert KA, Huhndorf S, Robert V. Spouge JL, Levesque CA, Chen W. 2012 - Fungal Barcoding Consortium. Nuclear ribosomal internal transcribed spacer (ITS) region as a universal barcode marker for Fungi. P Natl Acad Sci USA 109(16), 6241-6246.

Seynes MJD. 1869 - Observations Sur Le Genre Mycenastrum. Bulletin de la Société Botanique de France 16(2), 29-34.

Seynes MJD. 1886 - Um nouvelle espèce du Mycenastrum. Bulletin de la Société botanique de France 33, 78-80.

Silva JMC, Tabarelli M, Fonseca MT, Lins LV. 2004 - Biodiversidade da Caatinga: áreas e ações prioritárias para a conservação. Ministério do Meio Ambiente, Brasília pp. 382.

Smith HV, Smith AH. 1973 - The Non-gilled Fleshy Fungi. William Brown Inc., pp. 402.

Sousa JO, Morais LA, Nascimento YM, Baseia IG. 2014 - Updates on the geographic distribution of three Geastrum species from Brazilian semi-arid region. Mycosphere 5(3), 467-474.

Sousa JO, Suz LM, García MA, Alfredo DS, Conrado LM, Marinho P, Ainsworth AM, Baseia IG, Martín MP. 2017 - More than one fungus in the pepper pot: integrative taxonomy unmasks hidden species within Myriostoma coliforme (Geastraceae, Basidiomycota). PLoS ONE 12(6), e0177873.

Velloso AL, Sampaio EVSB, Pareyn FCC. 2002 - Ecorregiões propostas para o Bioma Caatinga. Associação Plantas do Nordeste, Instituto de Conservação Ambiental The Nature Conservancy do Brasil, Recife, pp. 76. 